\title{
UNIVERSITY STUDENTS' PERCEPTIONS OF THE INNER CITIES OF MURCIA AND VALENCIA
}

\author{
Francisco José Morales Yago ${ }^{1}$, María Luisa de LÁzaro y Torres ${ }^{1}$, \\ María Luisa GoMez Ruiz ${ }^{2}$ \\ ${ }^{1}$ Department of Geography, Universidad Nacional de Educación a Distancia, Madrid, Spain \\ ${ }^{2}$ Department of Didactics of Experimental, Social and Mathematical Sciences, Universidad Complutense de \\ Madrid, Spain
}

Manuscript received: May 13, 2018

Revised version: August 8, 2018

\begin{abstract}
Morales Yago F.J., LÁzaro y Torres M.L., Gómez Ruiz M.L., 2018. University students' perceptions of the inner cities of Murcia and Valencia. Quaestiones Geographicae 37(3), Bogucki Wydawnictwo Naukowe, Poznań, pp. 75-85. 10 figs, 3 tables.

ABSTRACT: Inner city perceptions create a mental representation from different approaches: a visual approach, carried out through observation and description; a second approach, focused on evaluation and analysis of a city; and a third approach, which integrates the feelings that a space evokes in individuals known as the sense of the place. In the final analysis the aforementioned approach condition the behaviour (action-decision) of individuals. Image capture mainly happens while people walk in, travel to or visit a city using different ways to get around and they organize a mental map of the city. University students were selected from two Spanish cities: Murcia (215 respondents) and Valencia (300 respondents) to reply to a survey and to draw a map of their city. Results of the images of the cities in which they were currently living also proved useful in providing guidelines on sustainable growth of cities and in detecting deficiencies in order to correct them. The research model could be used in other cities throughout the world.
\end{abstract}

KEY wORDS: geography of perception, mental maps, sense of place, Murcia, Valencia

Corresponding author: María Luisa de Lázaro y Torres, mllazaro@geo.uned.es

\section{Introduction}

The intellectual apprehension of space, its perception, creates a mental representation which can be expressed in a mental image in the form of a list, a map or a drawing. This perception is prior to observation (Liceras 2003); it is selective, depends on the individual's previous experiences and acts as a filter (Downs, Stea 1973). There are many factors of influence in perceptions: values and experiences which depend on age. Gould (1975) considers the development of capacities for spatial understanding according to age, as one of the important research lines. But there are also links with cultural heritage which depends on gender, literacy, level of instruction, ethnicity, religion and mobility. Relations between the real world and behaviour depend in part on perceptions. But also, landscape perceptions are a product of the transactions between individuals and landscapes (Zube 1987: 39).

Perceptions about cities would help in detection of problems to improve urban planning, and they serve various fields in urban studies including behavioural geography, urban design branding and tourists' destination management (Al-ghamdi, Al-Harigi 2015). Perception is a useful way of understanding cities, e.g. on inequality as was studied in Boston, New York, Linz and Salzburg (Salesses et al. 2013) using pairs of images (photos) of the cities to quantify people's perceptions. They asked questions such as, which 
place looks safer? or which place looks more upper-class? They validate data with statistics on security data and conclude that collaborative perception is a useful way to understand inequality and problems in the cities. On the topic of street trees, Graça et al. (2018) made a survey in Porto and concludes that people valued environmental benefits (particularly air quality improvement) more than cultural ones and that it is useful to integrate scientific knowledge and community opinions for evidence in planning and management. Perception studies on students' residing in metropolitan areas, such as Getafe (Madrid, Spain) show the development of their surroundings (Gómez Ruiz 2010).

\section{Research method}

A survey of university students (aged from 19 to 23 years old) from Murcia $(n=215,2017)$ and Valencia $(n=300,2014)$, with sketches of mental maps, was used to approach perception of the inner cities of Murcia and Valencia as a useful way to deal with cities' affairs. Three main ways were used (Zárate, Rubio 2011): visual (senses), carried out through observation and description following Kevin Lynch's (1960) study on Boston, Jersey City and Los Angeles. A second approach focused on valuated preferences (cognitive evaluation) following Peter Gould and Rodney White (1974). And a third one which integrates the feelings that space evokes in individuals known as the sense of the place (Tuan 1974). The aforementioned approaches have been found to condition behaviour (action-decision) of individuals.

After method explanation and a brief background of both cities (case study), this work will deal with results on:

- visual Lynch elements in both cities;

- preferences and evaluation of neighbourhood districts;

- other issues or key questions of the research: what would you miss on leaving the city or going to another one? what would you like to show to other visitors? And what is the use of the inner city?

- the last part will be perceptions related to feelings and the sense of place, to finish with discussion and conclusions.

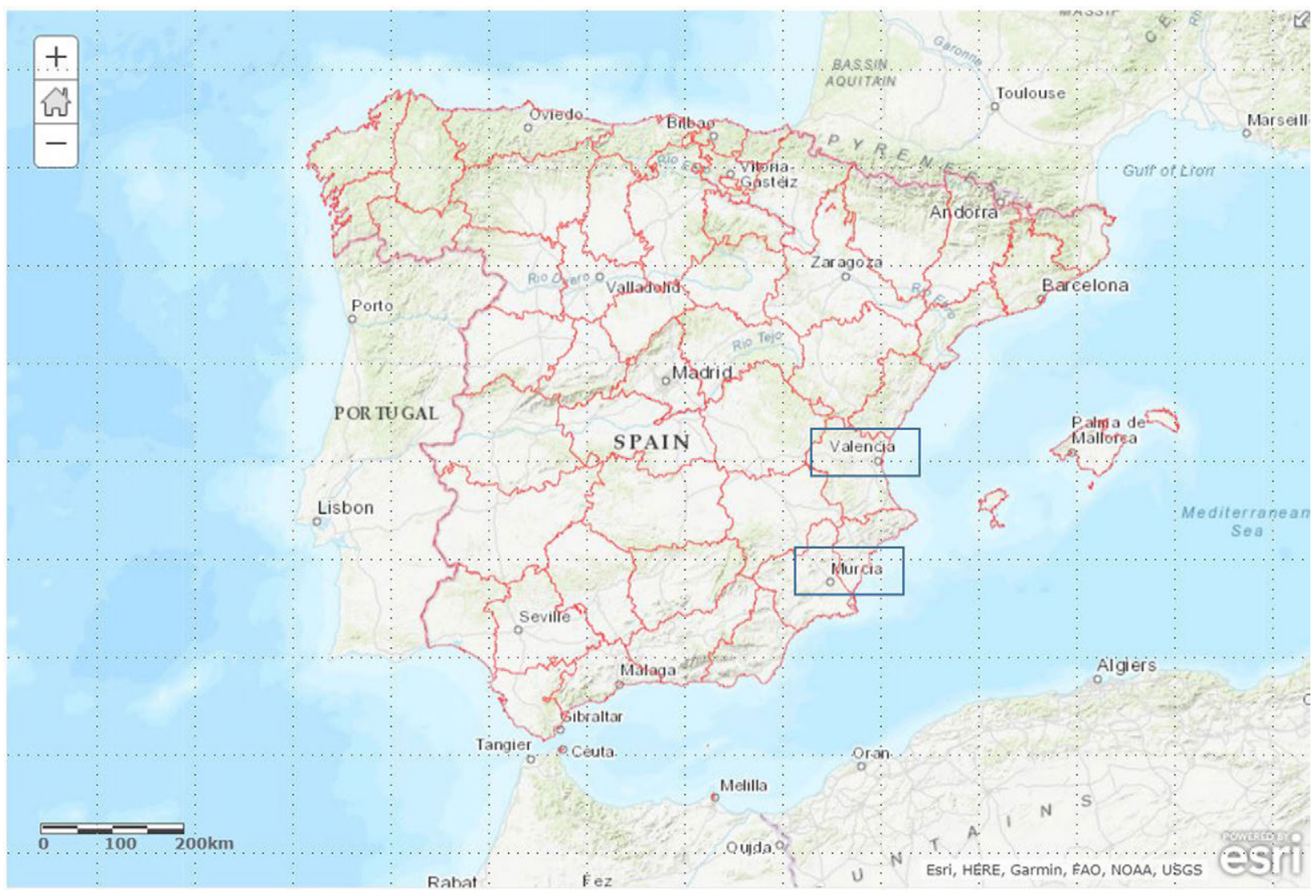

Fig. 1. Location of Murcia and Valencia. 


\section{Case study: Murcia and Valencia}

Murcia and Valencia are two medium-sized cities of 443,243 and 787,808 residents respectively (Spanish National Statistical Institute 2017) located in the SE of Spain (Fig. 1) and have not been previously compared on perception issues. They are both in flat fertile orchards. Murcia has not stopped its population increase, but Valencia's has slowed down since 2010. Both cities are crossed by a traditionally dry riverbed, in Murcia the Segura and in Valencia the Turia.

\section{Visual Lynch elements}

The adaptation of the Lynch model (1960) to different cities is not new. It has been used in the Spanish cities of Madrid (Bailly 1979), Segovia (García Ballesteros, Bosque Sendra 1989), Ourense (Somoza Medina 2005), Yecla (Morales 2012), A Coruña (González et al. 2015), Valencia (Morales 2015). Other cities such as Bordeaux (Escobar 1992), Bristol (Kelly, Kelly 2001), Sheffield (Shokouhi 2003), Tel Aviv (Casakin, Omar 2008), Armindale, New South Wales, Australia (Walmsley, Lewis 2014), have also being analysed under the Lynch model.

The five elements in Lynch's way (1960) of building the image of a city are:

- landmarks, specific points of reference, highlights on the map: buildings, monuments, stores or other geographical features;

- nodes, strategic points of the city where several paths converge (crossings or junctions) and it is possible for the observer to enter. They can be the symbol of the activity of a district, for example a square;

- paths, channels, streets, walks, canals, railroad tracks along which a usual, occasional or potential observer moves;

- districts, homogeneous areas with a common identity in the city and some characteristic which make them recognizable to an observer;

- edges, linear elements not used as paths. Lines of rupture of two urban textures (e.g. single-family and multi-family), or areas that separate one neighbourhood from another. They are borders or shores where development of the city stops.

Pocock and Hudson (1978) simplify these visual elements reducing them to three: punctual,
Table 1. Lynch element shapes

\begin{tabular}{|l|l|c|}
\hline \multicolumn{1}{|c|}{ Point } & Lines & Polygons \\
\hline Landmarks & Paths & Districts \\
\hline Nodes & Edges & \\
\hline
\end{tabular}

linear aspects and areas into which it is possible to integrate Lynch' categories (Table 1) and that are related to the vector model widely used today in Geographic Information Systems (GIS) and digital cartography.

\section{Valuate preferences}

The valued and preferential approaches, which refer to the appreciative dimension of the perception of the city, were done following Gould and White (1974). They considered very practical the ordinal scale (where 1 is the first chosen neighbourhood and $n$ the last preference). They showed that too many elements to choose from would fatigue respondents. Thus, we have used 1 to 5 elements. This type of study, in which a questionnaire to choose the preferred neighbourhoods, municipalities or provinces has been carried out for several Spanish cities such as Malaga province (Oliva 1982), Malaga municipality (Lázaro y Torres 1990) and Toledo (Zárate 1986), and the urban neighbourhoods of Rome (Bonaiuto et al. 1999). This study has been organized not only considering preferences on neighbourhood, but also other issues related to satisfaction of students in being living in those cities. For these reason two questions were considered: what they think they would miss if they leave the city and what they would you like to show to other visitors.

\section{Sense of place}

The concept of sense of place shows the perceptions from the relationship between humans and their environment, focused on the feelings that a space evokes among the citizens who live there on a day-to-day basis. One of the main authors is Tuan (1974) who provides a focus of the evaluative space in relation to feelings: topophilia (solid and affective bonds); topophobia (aversion, fear, rejection); topolatry (reverential and mythical character); toponegligence (indifference to the place). 


\section{Results on visual lynch elements}

\section{Perception of Murcia}

The main paths, nodes and landmarks of Murcia are delimited in a very significant way by students' sketches (Figs 2 and 3).

They identify the historic centre and other spaces that are part of the collective memory of the citizens. $87 \%$ of the respondents identify the main axes or traffic of the city and draw them. All of them identify the Gran Vía of Salzillo as the most remarkable path of the city. The Segura river or the main traffic axes are edges of the city. The most important landmarks (Fig. 4) are the Cathedral and surroundings, and also Los Milagros Bridge.

The most important nodes are the Round Plaza (Plaza Redonda), the Bus Station or La Fuensanta square, where a series of first-class streets converge, such as Gran Vía, Avenue of Liberty (Avda. Libertad), Jaime I or Avenue of the Constitution (Avda. Constitución). We summarize in Table 2 data from respondents according to Lynch's categories (1960).
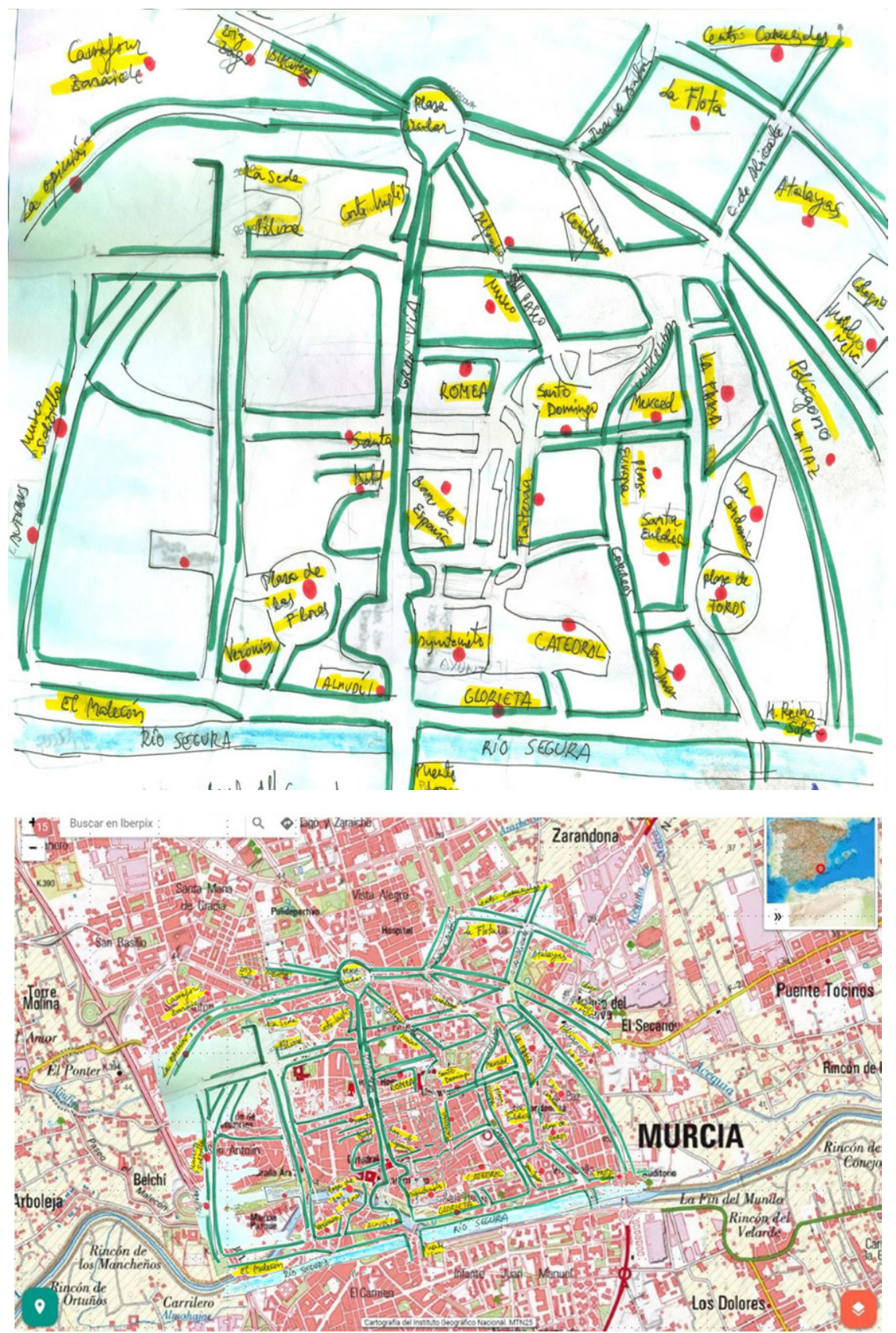

Fig. 2. A sketch of Murcia students' perception and the same perception on a real map of Murcia. 


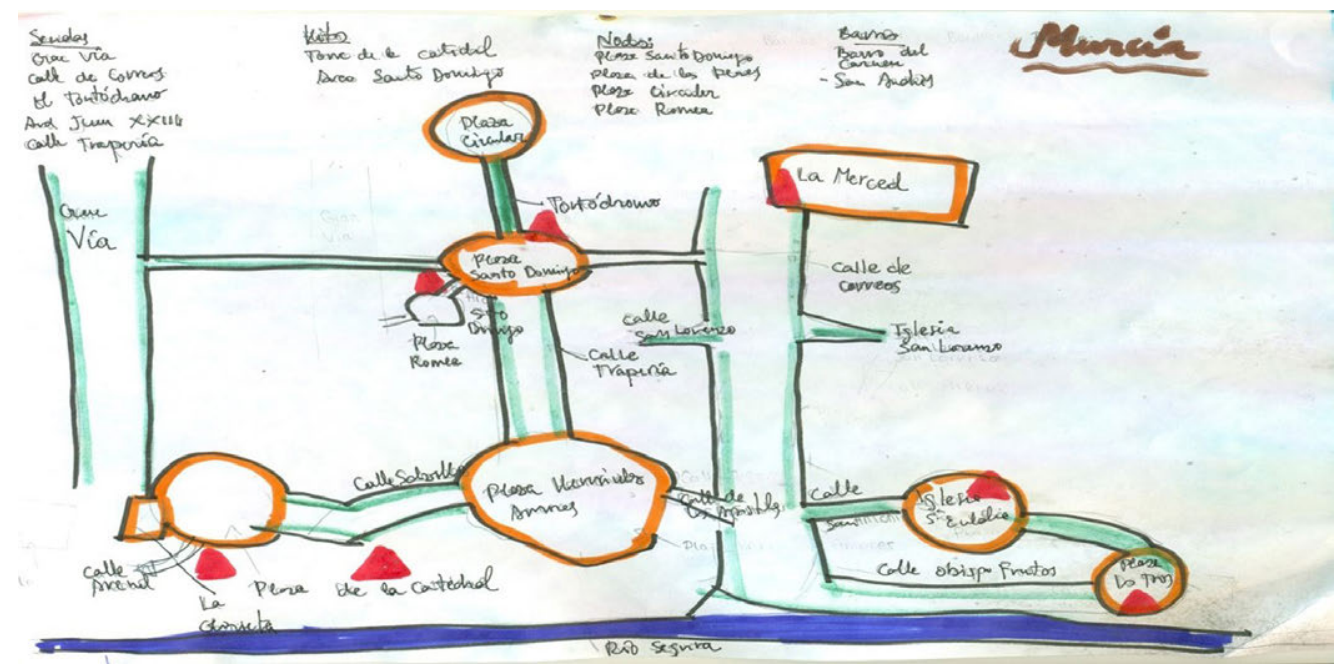

Fig. 3. A collective map of Murcia made by a group of 8 students presenting their perception about paths (sendas), landmarks (hitos), nodes (nodos) and districts (barrios). It highlights Murcia center-east because it is the traditional university leisure district. At the South, the Segura river as a border.

Table 2. Murcia elements highlighted by respondents in the categories established by Lynch (1960).

\begin{tabular}{|l|l|l|l|}
\hline \multicolumn{1}{|c|}{ Landmarks } & \multicolumn{1}{c|}{ Nodes } & \multicolumn{1}{c|}{ Paths } & \multicolumn{1}{c|}{ Edges or Borders } \\
\hline $\begin{array}{l}\text { Cathedral and cathedral } \\
\text { tower }\end{array}$ & $\begin{array}{l}\text { Santo Domingo, Romea, Las } \\
\text { Flores or Apóstoles Squares }\end{array}$ & Gran Vía Street & South ring road \\
\hline Bullring (Plaza de toros) & Town Hall & Paseo Alfonso X Street & Segura River \\
\hline $\begin{array}{l}\text { Town Hall (Ayuntamiento) } \\
\text { and Town Hall Square }\end{array}$ & $\begin{array}{l}\text { Redonda, Diez de Revenga } \\
\text { and Juan XXIII Square }\end{array}$ & Platería & Railway (El Carmen) \\
\hline Almudí Palace & Morales Meseguer Hospital & Trapería & Malecón \\
\hline Verónicas Market & Vieja Condomina & $\begin{array}{l}\text { Alejandro Seiquier (post- } \\
\text { office) }\end{array}$ & San Antón and Garay roads \\
\hline Segura river bridges & La Merced University & Avenida de la Fama & \\
\hline San Esteban & El Carmen railway station & Avda. Liberty (Libertad) & \\
\hline Las Claras & Bus station & Avda. Juan de Borbón & \\
\hline Romea Theatre & $\begin{array}{l}\text { Floridablanca and La Pólvo- } \\
\text { ra Gardens }\end{array}$ & Avda. Juan Carlos I & \\
\cline { 2 - 4 } & North and East roads & \\
\hline Casino & El Rollo & Avda. Floridablanca & \\
\hline Blue Towers & & Cartagena Street & \\
\hline Godoy Tower & & & \\
\hline
\end{tabular}

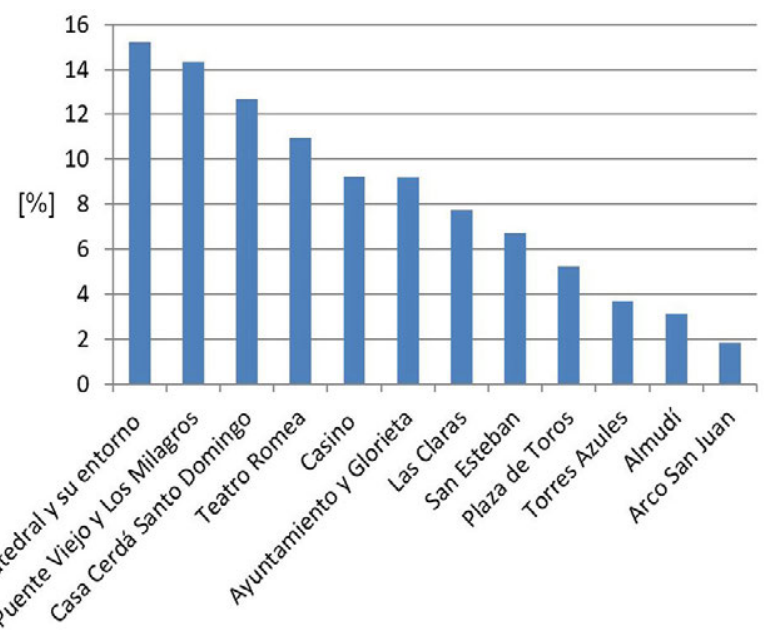

Fig. 4. Murcia landmarks according to survey results (\% of the total respondents).

\section{Perception of Valencia}

The landmarks perceived in Valencia according survey results are the City of Arts and Sciences (Ciudad de las Ciencias, whose official name is Ciutat de les Arts i les Ciències), the most important landmark, followed by the Cathedral and surroundings, the Town Hall, North Railway Station and Bullring (Fig. 5).

Students identify the historic centre in the urban area and also other spaces that are part of the collective memory of the citizens. They drew the main borders, paths, nodes and landmarks of Valencia (Figs 6 and 7).

Table 3 presents the places cited by respondents on the survey or drawn in the sketches. 


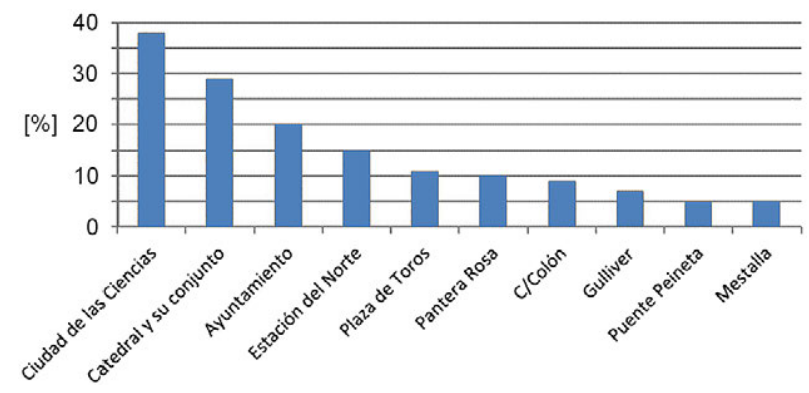

Fig. 5. Valencia landmarks according to survey results (\% of the total respondents).

\section{Results on preferences}

\section{On neighbourhood city districts}

The valued and preferential approaches, which refer to the appreciative dimension of the perception of the city, were done by asking individuals to select from a particular list of neighbourhoods. A topological map has been created with the results of respondents for Murcia and Valencia (Figs 7 and 8)

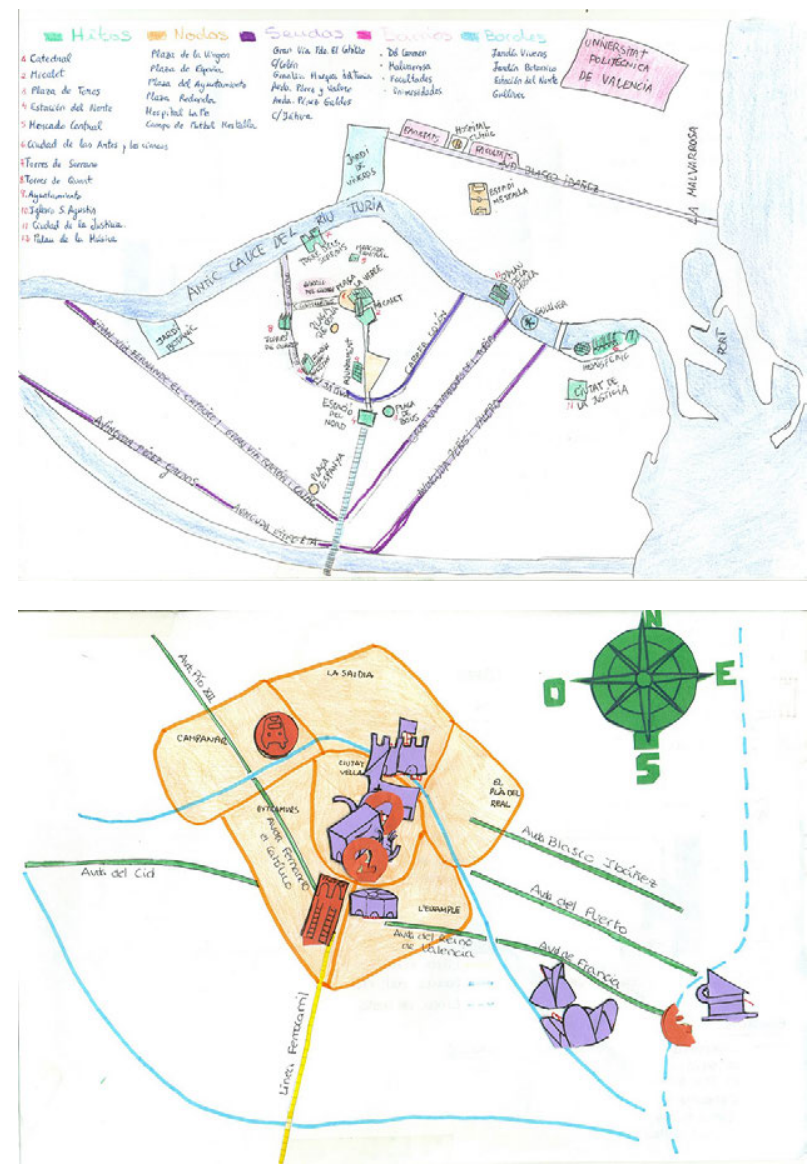

Both of the cases have the ensanche as the most highly rated place to live in. But this ensanche has different characteristics in Murcia and Valencia.

In Murcia, the ensanche is the part of the city near the historical city built in the $20^{\text {th }}$ century, as the city had had no economical increase in the $19^{\text {th }}$ century to need more dwellings. La Flota, Vistabella, Vistalegre and Santa María de Gracia are part of Murcia's $20^{\text {th }}$ century ensanche.

The ensanche in Valencia shows the growth of the city in the $19^{\text {th }}$ century, as in many others big cities in Spain. It was built following strict rules with modernist houses and subsequent growth of the city made it central, very well connected and with other infrastructures (commercial and cultural). Thus, it is very interesting for business and living. The Valencia ensanche consists of the neighbourhoods of Gran Vía Marqués de Turia Colón and surroundings, Ruzafa, and El Pla del Remei.

The central city/historical city follows the preference for ensanche. It is the urban center (centro urbano) in Murcia and San Francesc in Valencia.
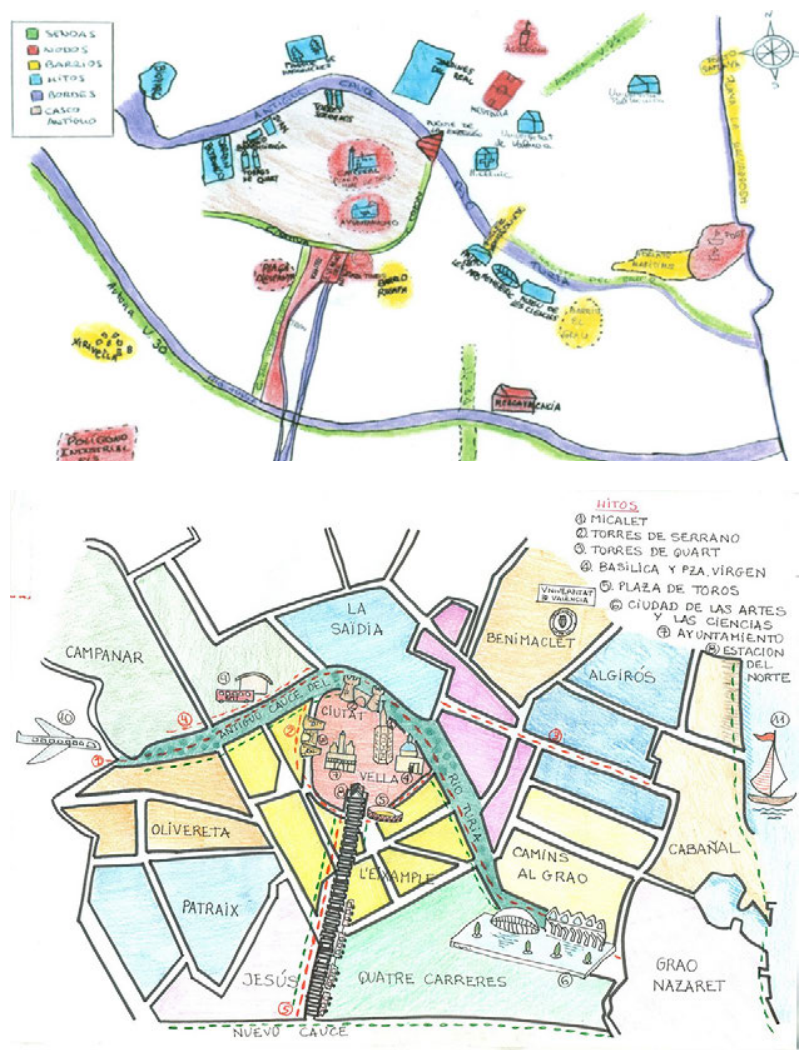

Fig. 6. Drawings of perceptions of Valencia made in groups of 6-9 university students of Valencia. 
Table 3. Valencia's elements highlighted by respondents in the categories established by Lynch (1960).

\begin{tabular}{|c|c|c|c|}
\hline Landmarks & Nodes & Paths & Edges or Borders \\
\hline \multirow[t]{3}{*}{ Cathedral } & La Virgen & \multirow{3}{*}{$\begin{array}{l}\text { Colón, Guillén de Castro and Xátiva } \\
\text { streets }\end{array}$} & \multirow{3}{*}{$\begin{array}{l}\text { Streets of La Pechina, De la } \\
\text { Alameda, Avda. Francia }\end{array}$} \\
\hline & La Reina & & \\
\hline & Town Hall & & \\
\hline Miquelet & $\begin{array}{l}\text { España and Redonda } \\
\text { squares }\end{array}$ & San Vicente Mártir & $\begin{array}{l}\text { Turia river (old and new } \\
\text { riverbed) }\end{array}$ \\
\hline Bullring & $\begin{array}{l}\text { La Fe Mestalla } \\
\text { Hospital }\end{array}$ & Ruzafa street & Railway \\
\hline $\begin{array}{l}\text { Ciutat de les Arts i les } \\
\text { Ciències }\end{array}$ & University & Barón de Cárcer & Sea border \\
\hline Serrano Towers & North railway station & $\begin{array}{l}\text { Avda. de Fernando el Católico/ } \\
\text { Ramón y Cajal }\end{array}$ & \\
\hline Quart Towers & Bus station & Pérez Gáldos/Giorgeta & \\
\hline Town Hall & & Perís y Valero/ Ausías March & \\
\hline La Música Palace & & Germanías/Marqués del Turia & \\
\hline $\begin{array}{l}\text { Central and Colon } \\
\text { Markets }\end{array}$ & & Blasco Ibañez/El Puerto avenue & \\
\hline Bridges & & & \\
\hline
\end{tabular}

After those, La Merced was very well rated in Murcia, as a good university and leisure environment, and the emblematic Santo Domingo and Romea squares. Also, Alfonso X El Sabio street. All of them considered as dynamic commercial, cultural and leisure places. The most recent high quality urban developments, such as the neighbourhood of La Flota, and Vista Alegre or San Antón, were also considered perhaps because of the high number of rental flats for university students. La Fama, La Paz and Vistabella are suffering a progressive degradation and they are perceived as insecure places, thus, they are not preferred for living. The population is ageing in San Andrés and San Antolín, and there are some buildings in a state of ruin and abandonment being occupied by immigrants. Social services, such as health centres and care spaces for the elderly, in peripheral neighbourhoods such as El Progreso or Los Rosales would be necessary.

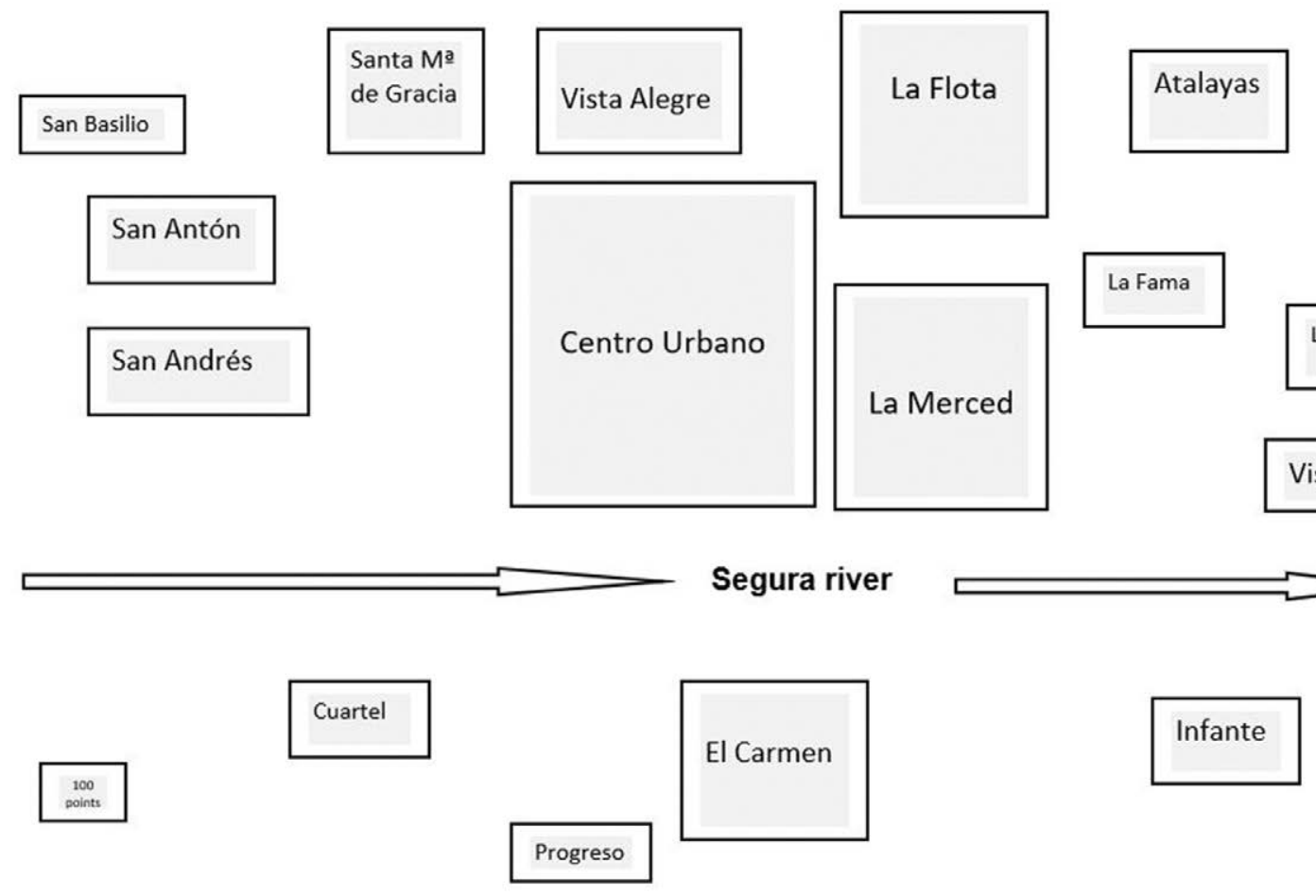

Fig. 7. Murcia's neighbourhoods. 


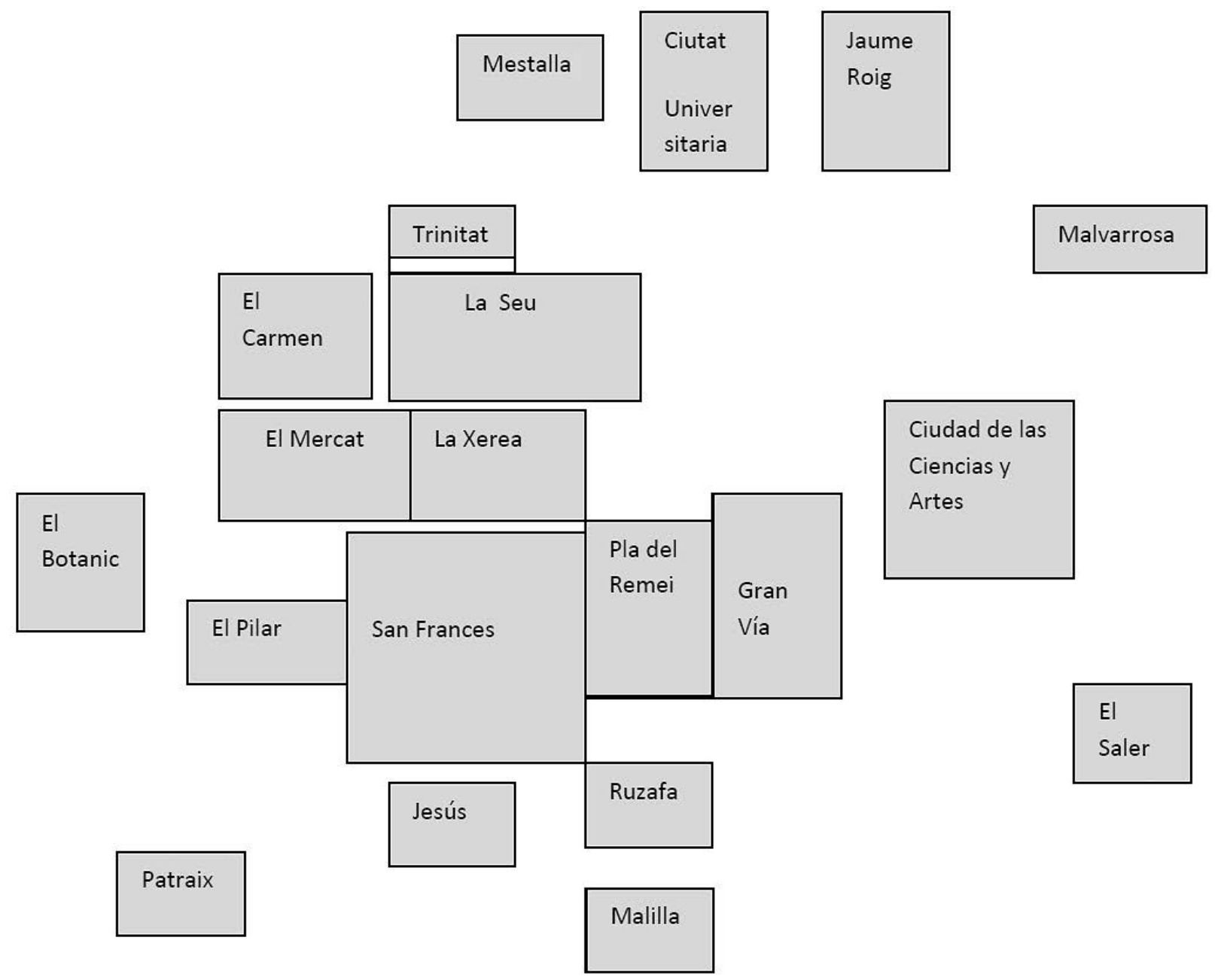

Fig. 8. Valencia's neighbourhoods.

\section{Murcia}

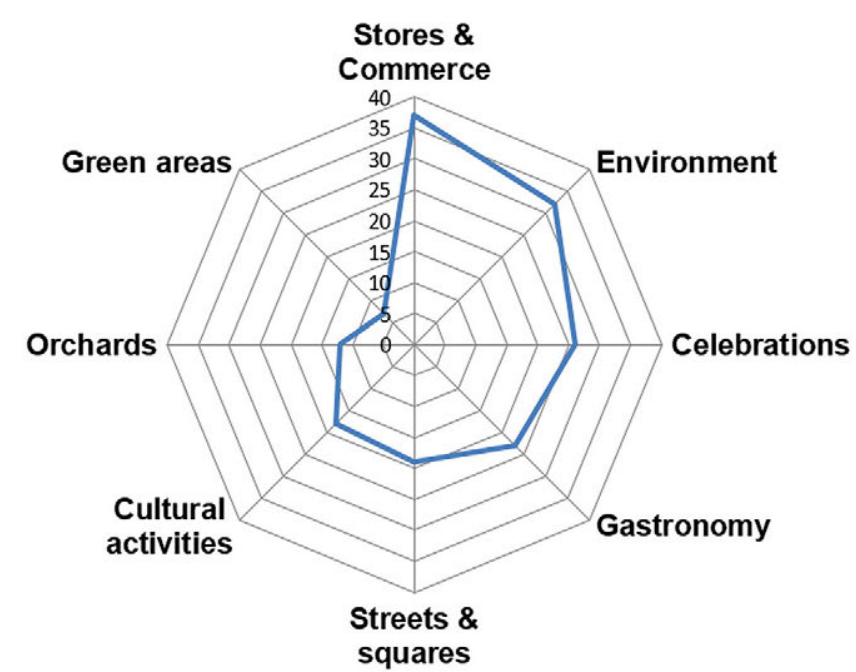

\section{Valencia}

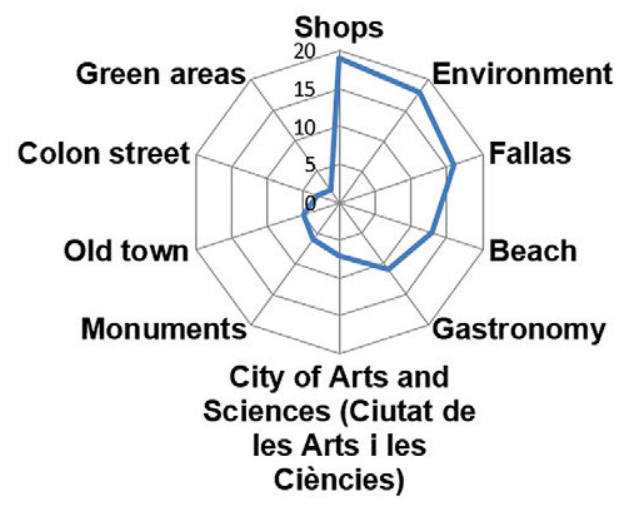

Fig. 9. Elements in Murcia and Valencia that respondents consider they would miss on leaving the city. 
Valencia's student respondents prefer, after the ensanche and the city centre, the surroundings of the University City (Ciutat Universitària), the City of Arts and Sciences (Ciutat de les Arts $i$ les Ciències) and the new urban developments on the coast near the harbour, beaches, Formula One circuit and shopping centres. Malvarrosa and Cabañal are places that they consider that it is necessary to be improved (rehabilitation).

\section{What would you miss on leaving the city?}

Surprisingly, it is not monuments or cultural affairs that people will miss, it is the shopping and commerce centres in both cases, perhaps because both cities are capitals of their region. The results can be seen on the spider chart below (Fig. 9). The second element is the way of leaving and environment, and also the local parties, festivities or celebrations (in Valencia the Fallas are very famous). The beach, in Valencia, and the cuisine, in Murcia which comes from the excellent orchards crops, are also appreciated things. Both cases are very similar. Green areas are not the most important thing for them.

\section{What would you like to show to other visitors?}

Respondents aware on the cathedral, as one of the main landmarks to show to others. It is the same in other cities such as Segovia (García Ballesteros, Bosque Sendra 1989) or Bristol (Kelly, Kelly 2001). Key streets such as the Malecón, the Town Hall, Museums (e.g. Salzillo), the Real Casino and some other nice streets are also important in Murcia.

The famous original initiative of the City of Sciences and Arts (Ciudad de las Ciencias y las Artes / Ciutat de les Arts i les Ciències), a big entertainment place based on cultural (e.g. an interesting interactive Museum) and a modern architectural complex in Valencia. Beaches, the inner city and the Bullring are also attractive places to show to other visitors according to respondents' opinions (Fig. 10).

\section{Results on sense of place}

After looking into the study, it is not very difficult to see the relations of students with the cities of Murcia and Valencia.

Again, we can stress some common characteristics. There is a strong affective relationship (topophilia) with the Town Hall and surroundings. In the case of Valencia, the main Falla festivity during the yearly March celebration is located in the square of the Town Hall, thus, many people tend to go there. A reverential feeling (topolatry) is presented with the cathedrals. It is not a surprise as they were important landmark and both of them are important monuments of the cities. In
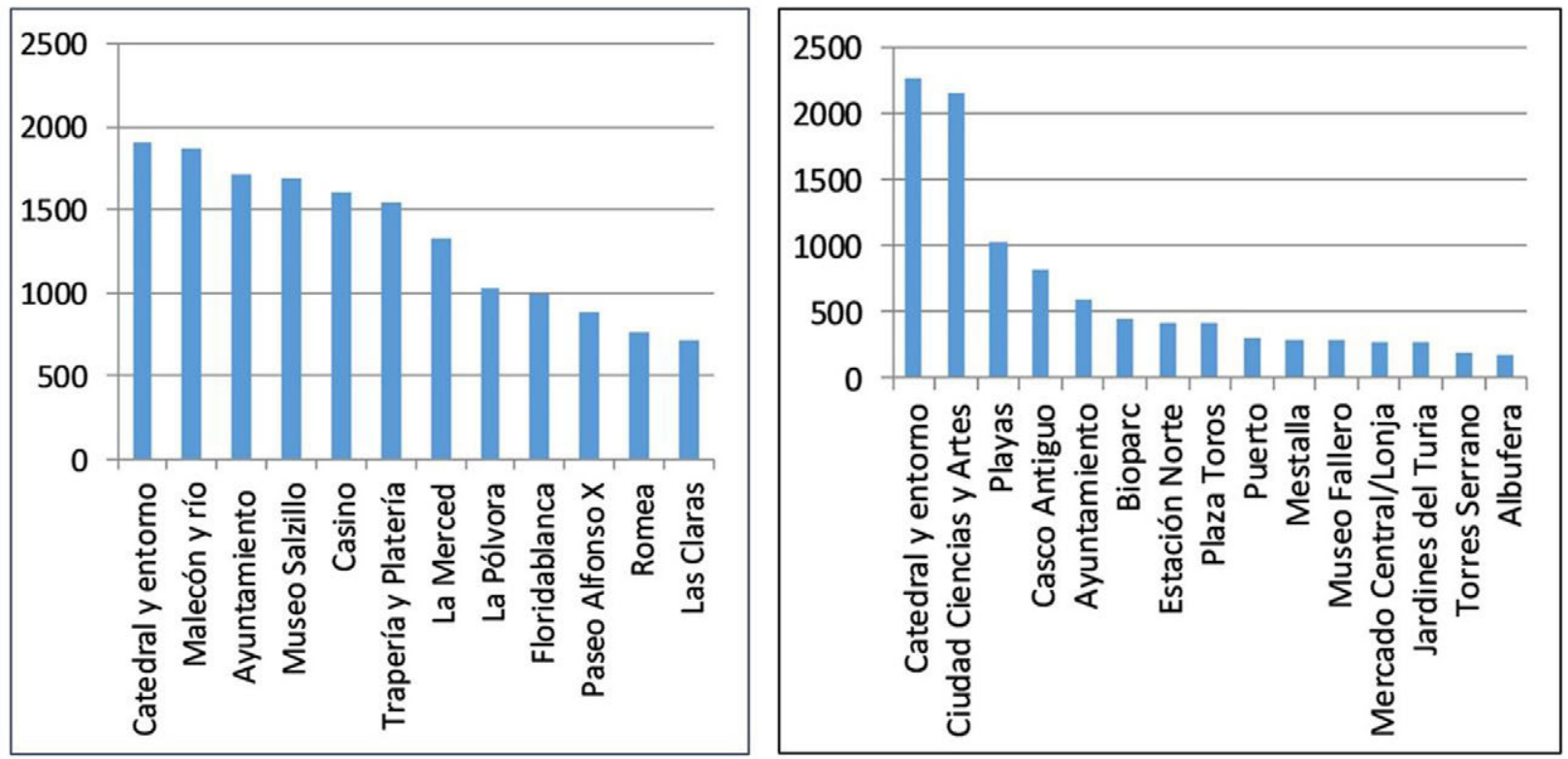

Fig. 10. Places to show to other visitors, the scores assigned according to the responses of the surveys in Murcia (left) and Valencia (right). 
Murcia there is also topolatry with regard to other monuments such as the Real Casino and Fontes Palaces. The new houses built for the shantytown population make students to consider as insecure places, La Paz or La Fama in Murcia or La Coma, Torrefiel, Fuensanta/La Luz in Valencia. Some of them have a hatred relationship that includes fear (topophobia) in relation to these places. It is difficult to draw conclusions about indifferent places as people usually ignore them.

Thus, the sense of place approach does not differ very much from the previous approaches in neighbourhood preferences.

\section{Discussion}

Some reflections on perceived space are made by different classical authors such as Humboldt in Kosmos. He states that to understand the sublimity of nature, it is necessary to consider it first objectively, as a real phenomenon, and then subjectively, as reflected in the feelings of the humans. In this study we refer to the second topic, the space of two Spanish cities, Murcia and Valencia, as a subject using there different perception approaches to reach conclusions: A visual approach (senses) obtained by observation and description (Lynch 1960); An approach focused on preferences (cognitive evaluation) (Gould, White 1974) and an approach which integrates the feelings that a space evokes in individuals known as the sense of the place (Tuan 1974).

Knowledge collected can be used for (participatory) action in that it is considered as an important value in planning. Murcia is keeping its population in spite of the aging. It has a great immigrant impact, people who have generally occupied the buildings with the worst hygienic-sanitary conditions. Valencia, in spite of the traffic problems, and lack of accessibility and infrastructures of some neighbourhoods, has had great success with the renovation of the Turia River area, where the City of the Science and Arts is located.

The study would be completed with other research lines, from psychology or integrating the use of Information and Communication Technologies (ICT) (Al-ghamdi, Al-Harigi 2015) for users and evaluate if inhabitants' virtual perceptions of cities have any influence on perception of the city. There is a strong research line in collecting these data not on sketches or traditional surveys, but by using GeoICT such as Survey123, or by making a collaborative Story Map or using an editable overlay on ArcGIS Online. These would be useful in future studies.

\section{Conclusions}

Students are satisfied with their cities, and they have described the importance of shopping, leisure, beach, gastronomy, city celebrations (e.g. Las Fallas), but they have not stressed cultural affairs very much. They only think of cultural items when they think of showing their own city to others.

The most favourite area for living is not the inner city, it is the ensanche, however most of the landmarks are in the inner city. Rehabilitation (the improvement of buildings) made gentrification processes possible for ageing neighbourhoods.

The understanding and preferences that the citizens of a town or city have about the space they live in is very useful information for different aims, such as planning or management of the city. Thus, they have identified some problems in the city which could be reported to the interested parties (such as participatory citizens): inner cities need to be improved in terms of infrastructures, degradation, aging population and old building, as can be seen in specific places of the inner cities.

Rehabilitating and revitalizing the central space, as a cultural and commercial axis would solve some degradation problems. The three perception approaches seem adequate for these kinds of studies, all of them are complementary to the others.

\section{Acknowledgements}

We would like to thank reviewers for their advice and wise revision.

\section{References}

Al-ghamdi S.A., Al-Harigi F., 2015. Rethinking Image of the City in the Information Age. Procedia Computer Science 65: 734-743.

Bailly A., 1979. La percepción del espacio urbano. Madrid: Instituto Estudios de Administración Local. 
Bonaiuto M., Aiello A., Perugini M., Bonnes M., Ercolani A.P., 1999. Multidimensional perception of residential environment quality and neighbourhood attachment in the urban environment. Journal of Environmental Psychology 19(4): 331-352.

Casakin H., Omar I., 2008. What Features and Structural Relationships make the Streets of Tel Aviv City being Legible? An Urban Design Perspective. In: P.Maiti (ed.), Negation to Negotiations-Solving the Puzzles of Development, New Delhi: 375-391.

Downs R.M., Stea D., 1973. Image and Environment: Cognitive Mapping and Spatial Behavior. Chicago: Aldine Publishing Company.

Escobar Martínez F.J., 1992. El esquema cognitivo del espacio urbano. In: Bosque Sendra J., Castro Aguirre C. de, Diaz Muñoz M.A., Escobar Martinez F.J. (eds.), Prácticas de Geografía de la percepción y de la actividad cotidiana. OikosTau, Barcelona: 45-100.

García Ballesteros A., Bosque Sendra J., 1989. El espacio subjetivo de Segovia. Editorial Universidad Complutense, Madrid.

Gómez Ruiz M.L., 2010. El tratamiento de los procedimientos en la geografía del bachillerato: nuevas propuestas de metodología activa a partir de la investigación empírica. PhD Thesis, Universidad Complutense, Madrid: 159-212.

González M.Á., Dopico J.A., Campos-Juanatey D., 2015. La imagen pública de la ciudad de A Coruña. Revista de Estudios e Investigación en Psicología y Educación Vol. Extr. 1: 182-186.

Gould P., White R., 1974. On mental maps, Penguin Books.

Gould P., 1975. People in information space: The mental maps and information surfaces of Sweden. Gleerup.

Graça M., Queirós C., Farinha-Marques, P., Cunha M., 2018. Street trees as cultural elements in the city: understanding how perception affects ecosystem services management in Porto, Portugal. Urban Forestry \& Urban Greening 30: 194-205.

Kelly A., Kelly M., 2001. Building legible cities. Bristol Cultural Development Partnership, Bristol.

Humboldt A.V., Kosmos. Vol. 1. There are different translations along the second part of 19 century.

Lázaro y Torres M.L. de, 1990. La Geografía de la Percepción: Análisis de las Preferencias Residenciales. Aplicación al Municipio de Málaga. In I Congreso de Jóvenes Historiadores y Geógrafos. Editorial de la Universidad Complutense de Madrid: 55-62.

Liceras A., 2003. Observar e interpretar el paisaje: estrategias didácticas. Grupo Editorial Universitario.

Lynch K., 1960. The image of de city. MIT Press. Cambridge.

Morales F.J., 2012. La geografía de la percepción: una metodología válida aplicada al caso de una ciudad de tipo medio-pequeño. El ejemplo de Yecla (Murcia). Papeles de Geografía 55-56: 137-152.

Morales F.J., 2015. La ciudad de Valencia como espacio percibido para los estudiantes universitarios. Aportaciones desde el análisis propuesto por la geografía de la percepción. Estudios Geográficos. LXXVI(278): 203-233.

Oliva J., 1982. Ensayo de mapificación cognitiva. Prefencia residencial de la provicia de Málaga. Cuadernos Geográficos de la Universidad de Granada 10: 27-50.

Pocock D., Hudson R., 1978. Images of the urban environment. New York, Columbia University Press.

Salesses P., Schechtner K., Hidalgo C.A., 2013. The collaborative image of the city: mapping the inequality of urban perception. PLOS ONE 8(7): e68400.

Shokouhi M., 2003. Legible cities: The role of visual clues and pathway configuration in legibility of cities. In: Proceedings of 4th International Space Syntax Symposium, London. Online: www.spacesyntax.net/symposia-archive/SSS4/ fullpapers/71Shokouhipaper.pdf (accessed August 8,2018)

Somoza Medina J., 2005. La geografía de la percepción como instrumento de ayuda al planeamiento urbano. Un posible ejemplo en la ciudad de Orense. Biblioteca Virtual Miguel de Cervantes. II Jornadas de Geografía Urbana. Alicante: $307-314$.

Spanish National Statistical Institute, 2017. Census Data 2017. Online: www.ine.es.

Tuan Y., 1974. Topophilia. A study of environmental perception, attitudes, and values. Columbia University Press.

Walmsley D.J., Lewis G.J., 2014. People and environment: Behavioural approaches in human geography. Routledge.

Zárate M.A., 1986. Una aproximación a la geografía de la Percepción, Didáctica Geográfica 14: 43-64.

Zárate M.A., Rubio M.T., 2011. Paisaje, Sociedad y Cultura en Geografía Humana. Ed. Ramón Areces, Madrid.

Zube E.H., 1987. Perceived land use patterns and landscape values. Landscape ecology 1(1): 37-45. 